Article

\title{
Sustainability Assessment of Traditional Agroecosystems in the High Region of Yaonáhuac, Puebla, Mexico
}

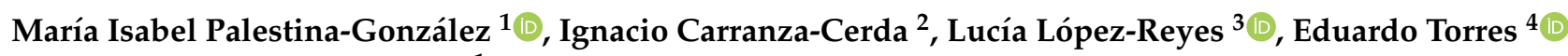 \\ and Sonia Emilia Silva-Gómez ${ }^{1, *}$ \\ 1 Ciencias Ambientales, Benemérita Universidad Autónoma de Puebla, Puebla 72570, Mexico; \\ palestina25@hotmail.com \\ 2 Gestión del Desarrollo Social, Colegio de Posgraduados, Campus Puebla 72760, Mexico; icarranz@colpos.mx \\ 3 Centro de Investigación en Ciencias Microbiológicas, Benemérita Universidad Autónoma de Puebla, \\ Puebla 72570, Mexico; lucia.lopez@correo.buap.mx \\ 4 Centro de Química, Benemérita Universidad Autónoma de Puebla, Puebla 72570, Mexico; \\ eduardo.torres@correo.buap.mx \\ * Correspondence: soemsigo@gmail.com
}

\section{check for} updates

Citation: Palestina-González, M.I.; Carranza-Cerda, I.; López-Reyes, L.; Torres, E.; Silva-Gómez, S.E. Sustainability Assessment of Traditional Agroecosystems in the High Region of Yaonáhuac, Puebla, Mexico. Environments 2021, 8, 40. https://doi.org/10.3390/ environments 8050040

Academic Editors:

Zacharias Frontistis and Rik Leemans

Received: 1 March 2021

Accepted: 23 April 2021

Published: 30 April 2021

Publisher's Note: MDPI stays neutral with regard to jurisdictional claims in published maps and institutional affiliations.

Copyright: (c) 2021 by the authors. Licensee MDPI, Basel, Switzerland. This article is an open access article distributed under the terms and conditions of the Creative Commons Attribution (CC BY) license (https:// creativecommons.org/licenses/by/ $4.0 /)$.

\begin{abstract}
A Sustainability Index for Traditional Agroecosystems (SITA) applied in Yaonáhuac, Puebla, Mexico was built. The index was composed of 16 indicators, with which the analysis of diversityresilience, self-management-autonomy, integration, and self-sufficiency was carried out. To determine the type of sustainability, 62 in-depth interviews were applied to inhabitants of the municipality of Yaonáhuac. The results showed that the following indicators increased the sustainability of home gardens: soil fertility properties, agricultural heterogeneity, linking practices with the home garden, family participation, non-participation in government subsidies, agricultural local knowledges, uses of plants, material of the fence or boundary, productive diversity, and destination of crops. It was found that 29 home gardens showed super strong sustainability and 31 had strong sustainability. The SITA can be used to research small-scale traditional agroecosystems with similar characteristics to monitor their sustainability, as well as to assist in decision-making and promote agroecological management from the home. The shown data represent initial information to monitor and propose agroecological transitions in that region.
\end{abstract}

Keywords: agroecology; home gardens; small-scale agroecosystems; sustainability index

\section{Introduction}

Research into sustainable agriculture requires integrating social, cultural, and environmental aspects based on the perception and conception of agriculture and the lifestyle of the peasants [1-3]. Researchers have showed special interest in traditional agroecosystems, where peasants preserve the agricultural knowledge systems, local crops, and a variety of animals under native forms of social and cultural organization. These agricultural systems are managed with the accumulated experience of the peasants or the native communities that have interacted with their surroundings $[4,5]$. The traditional agroecosystems are systems strongly linked to an ecological rationality, and are characterized by a wide diversity of crops and domesticated animals; this diversity is kept by complex systems of local knowledge [6].

The traditional agroecosystems provide information on the traditional practices and strategies that can serve as a basis to monitor and propose agroecological transitions in the region; these consist of reconfiguring the different components of an agroecosystem and its interactions through a design process based in a set of criteria to achieve the scale-up of the agroecology, with the participation and organization of the farming community. The purpose is to preserve and enhance the social, cultural, biological, and economic environment, and to bind the traditional knowledge of the native community with that of the academic community [7-11]. 
There are two important reasons as to why the traditional agroecosystems are a subject of interest in the research on sustainable agriculture. The first one is that the agroecosystems have persisted; they represent models that promote biodiversity and maintain the annual yields despite the economic and environmental changeability [6]. The second reason is that with its multiple functions they supply different values to the agroecosystem and the peasants; among these values the ecological services, the value of the means of life and the social and political implications, are found [12]. In the last two decades, researchers have shown interest in the biophysical components and interactions present in the traditional agroecosystems, focusing on the environmental, economics, and social areas $[13,14]$. There have also been others that have widened their research to involve the socio-cultural and the agricultural-environmental aspects [15].

However, from all the above-mentioned areas, the interest on the economics dimension is the one that stands out. For instance, Flores and Sarandón [16] have pointed out that the viability of the agricultural systems has been studied based on the cost-benefits analysis, where these benefits and costs are expressed in monetary units. This has important limitations from an agroecological approach because it does not take into account agrienvironmental and biocultural variables. Furthermore, Astier et al. [14] mention that in terms of sustainability indicators, more attention has been given to the environmental and economics dimensions.

Based on these arguments, it is necessary to evaluate the mentioned areas, but from an agroecological point of view considering the local knowledge systems, adding the biocultural dimension to determine the sustainability of the traditional agroecosystems in an equilibrated way $[7,17-19]$.

The investigation is focused on a particular type of a traditional agroecosystem, that is, a home garden. It can be found worldwide, can be defined as an agroforest system, generally implemented in the backyard of a house, and depending on the rainfall on each geographical region, it is watered with rainwater or with other irrigation systems taking water from springs or wells. A home garden is a space occupied by domestic and semi-domestic plants used as food, fuel, construction materials, medicinal plants, for decoration and to provide shadow, combined with domestic animals [20]. The home garden is normally fertilized with organic fertilizer, can supply diverse crops and its economic importance lies in its medicinal, nutritional and alimentary value in homes, and it plays a crucial role in the conservation of diverse species because it can be productive all year long [4].

The home gardens have been studied as sustainable agricultural systems [4,20]. However, understanding and evaluating the sustainability of the agri-food systems still represents a challenge [15], because a home garden is also an interdependent socio-ecological system and it includes agroecological, economic and political-social domains, that interact and are tied to their own complex dynamics [21]. Under this premise, the principles of diversity-resilience, self-management-autonomy, integration, and self-sufficiency linked to four dimensions (agri-environmental, social, biocultural and economic), can be taken as a framework to evaluate the sustainability of home gardens, where the local knowledge of the peasants is crucial for a thorough study $[20,22,23]$.

\section{Home Gardens and Sustainability}

The agroecological knowledge based on the experience of the peasants is the necessary component to develop sustainable agriculture. Such knowledge presents a viable way toward healthy and accessible foods, the protection of the environment and human dignity [24,25]. In Mexico, rural producers together with scientists, technicians, NGOs and other actors co-produce new alternative and hybrid knowledge that gives visibility and legitimacy to local actors [19].

In Sekhukhune, South Africa the food production is achieved through a subsistence agriculture, where cereals, legumes and vegetables are grown, although the vegetables also grow spontaneously. The crops are produced to guarantee the availability and accessibility 
of foods at household levels; these traditional practices in home gardens are useful to eradicate poverty and assure wellness and a healthy life [26].

Singh et al. [27] showed that in Arunachal Pradesh, India, the home gardens are an important source of diverse food plants; 14 species of plants had alimentary use, 33 were used as food and ethnomedicine, and 13 species represented a means to generate income. They noticed that 17 animal species also play a crucial role in the local diet and in keeping the cultural identity. The authors also argue that women from the Adi ethnicity that live in the faraway communities have a wide knowledge about local alimentary species that are preserved by tested traditional practices, improving the biocultural diversity and the socioecological resilience.

Zhang et al. [28] obtained information about the Yarlung Tsangpo home gardens at the Great Canyon in Southeast China, where 196 ethno-species were collected and categorized in 14 groups. These groups were formed according to their use and the most important were the vegetable, the ornamental, the medicinal and the fruit production uses. The characteristics, life forms, habits, habitats and use values of the plants are representative of the local knowledge of the population. This information was obtained through observation, intuition, experience, and assays, and was later summarized as a local knowledge in their own language. The home gardens supplied the products and necessary services to support the everyday life of the local population.

Finally, Avilez et al. [29] recently published their study about the multifunctionality of the home gardens in Tabasco, Mexico. A total of 280 species were inventoried, from which $33.2 \%$ were native, $26.4 \%$ were of neotropical origin and $40.4 \%$ were introduced. The authors registered and analyzed 38 functions of the home gardens, from which 14 were in the ecological dimension, 12 were in the economics dimension, and 12 in the sociocultural dimension. They concluded that the contemporary knowledge related to the multifunctionality of the home gardens is an important asset for the preservation of the agrobiodiversity, for it is an integral part of the local livelihood.

The principles are defined below: diversity-resilience, self-management-autonomy, integration, and self-sufficiency linked to four dimensions (agri-environmental, social, biocultural, and economic), which are proposed as a framework to evaluate the sustainability of home gardens (Table 1).

Table 1. Dimensions and principles for evaluating the sustainability of home gardens.

\begin{tabular}{|c|c|c|}
\hline Dimensions & Principles & References \\
\hline $\begin{array}{l}\text { Agri-environmental. Relationships } \\
\text { between soil, crops, animals, and } \\
\text { agricultural activities. }\end{array}$ & $\begin{array}{c}\text { Diversity- Resilience. It is shown when a bio-cultural } \\
\text { complex links to a population, whose practices maintain } \\
\text { and restore the quality of an agricultural system to } \\
\text { ensure food supply. }\end{array}$ & {$[6,7,21,30-32]$} \\
\hline $\begin{array}{l}\text { Social. Relationships between family, } \\
\text { inputs, benefits, and } \\
\text { government subsidies. }\end{array}$ & $\begin{array}{l}\text { Self-management-Autonomy. It is the capacity of an } \\
\text { agroecosystem to function with its own resources; the } \\
\text { use of goods and decision-making responds to the level } \\
\text { of organization of the family. }\end{array}$ & [33-35] \\
\hline $\begin{array}{l}\text { Bio-cultural. Relationships between } \\
\text { knowledge, use of plants, adaptation, } \\
\text { and existence of living fences. }\end{array}$ & $\begin{array}{l}\text { Integration. It takes up a set of beliefs and knowledge } \\
\text { that families culminate in practices to meet material and } \\
\text { spiritual needs (Kosmos-Corpus-Praxis). }\end{array}$ & {$[22,23,36,37]$} \\
\hline $\begin{array}{l}\text { Economic. Relationship between } \\
\text { productive diversity, destination of crops } \\
\text { and animals, and generation of } \\
\text { commercialization channels. }\end{array}$ & $\begin{array}{l}\text { Self-sufficiency. Regarding enough diversity of products } \\
\text { to meet the needs of consumption and } \\
\text { commercialization. }\end{array}$ & {$[7,38]$} \\
\hline
\end{tabular}

Sustainability can be classified into weak, strong, and super strong. A weak sustainability gives priority to economic valuation; the environmental components are priced and subject to property rights. Nature is another factor of production and is perceived as natural capital, highlighting the instrumental values. Strong sustainability protects elements of nature and ensures the permanence of the ecosystems and the species that represent a 
critical natural capital that cannot be converted into other forms of capital; an economic and ecological value prevails, with an anthropocentric approach. Super strong sustainability conceives a plurality of knowledge and valuations of nature (economic, ecological, ethical, social, cultural, aesthetic and religious), with a biocentric approach; nature is perceived as a natural heritage that is received as an inheritance and must be maintained and preserved to be handed over to future generations [39-44].

The objective of this study was to determine the type of sustainability by means of a Sustainability Index for Traditional Agroecosystems (SITA), which was constructed with indicators related to the above-mentioned principles. The SITA can be used to research small-scale traditional agroecosystems with similar characteristics to monitor their sustainability, as well as to assist in decision-making and promote agroecological management from the home. The shown data represent an initial information to monitor and propose agroecological transitions in that region.

\section{Materials and Methods}

\subsection{Study Region}

The research was performed in Puebla, Mexico, between the $19^{\circ} 52^{\prime} 15^{\prime \prime}$ North latitude and $97^{\circ} 27^{\prime} 59^{\prime \prime}$ West longitude [45]. The region has an altitude between 300 and $1900 \mathrm{~m}$ above sea level; the soil is mainly andosol, its temperature varies from 14 to $22{ }^{\circ} \mathrm{C}$, with a rainfall range between 1400 and $3600 \mathrm{~mm}$, and it has two kinds of climate: damp semiwarm with rains all year (68\%) and damp warm with rains all year (32\%). It is located between the cloud forest mountain and the pine-oak forest ecosystems [46] and has a population of 8018 inhabitants [47].

The study region was specifically located among the 11 towns that comprise the high region of the municipality, where a large number of inhabitants gather predominantly for agricultural activities (Yaonáhuac, Ahuata, Mazatonal, Talcozamán, Tatempan, Contzitzintán, Atemeya, Tepantiloyan, Acocogta-Poctan, El Crucero y Ahuehuetitan) (Figure 1).

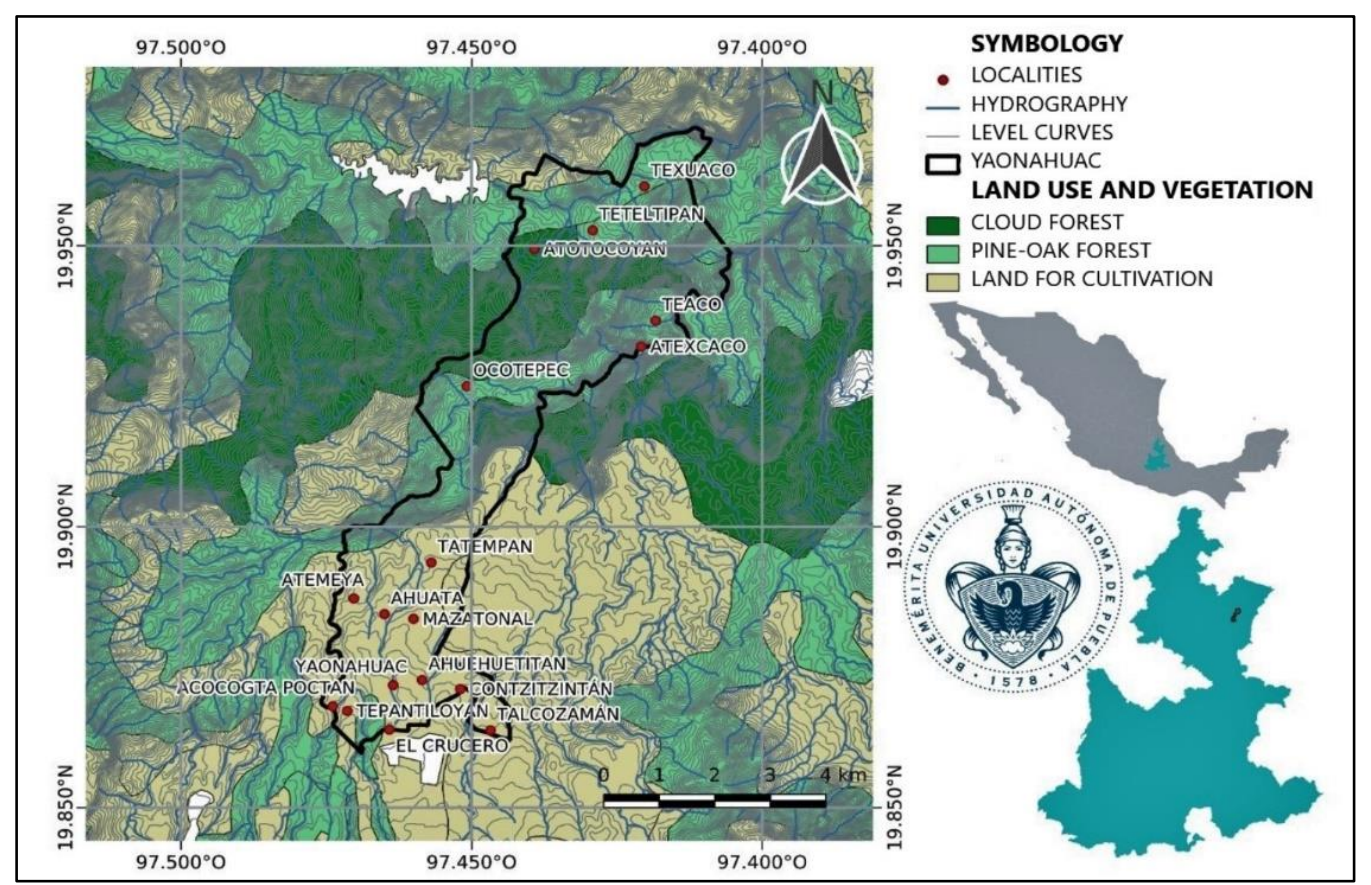

Figure 1. Location and land use and vegetation map of Yaonáhuac, Puebla. Prepared by the authors with information from INEGI [48].

\subsection{Data Gathering}

One sampling was done by convenience. In total, 62 families were interviewed, their ages between 29 and 94 years old and an average of $57.9 \pm 13.6$. The information was 
gathered during the agricultural cycle in 2018. The agri-environmental data were gathered during the participatory field trips. The socioeconomic data were collected through direct observation and in-depth interviews. The questions included the number of members, their age, relation, education, their role in the home garden and their perception of the natural surroundings. Five criteria were considered to interview the members: that they were residents in the study region; that they owned a home garden; that they were $>25$ years old; that the home garden had been functioning for 5 years or more, and that they were available to participate. The biocultural data included aspects about the approximate size of the home garden, the boundaries and fences, the diversity of the crops, the animal husbandry, the knowledge, and habits linked to the crops, the local knowledge, uses and names in Spanish and in Nahuatl of the plants as well as the management and structure of the home gardens.

The obtained data were organized, classified, and analyzed by thematic content according to Table 1. A descriptive analysis was also performed.

\subsection{Index Construction}

We consulted articles that described in detail the agroecosystem involved, the concept of sustainability, the theoretical-conceptual framework for the index, the weighting of the indicators and the variables considered $[3,15,16,49-51]$. With the literature consulted, a broad list of indicators has been developed according to the type of agroecosystem. The most representative of the local context were chosen by consulting experts, to obtain a main list of 16 indicators. In the sustainability evaluation, the principles were considered equally important (25\% maximum contribution each); the aim was to achieve a balance between the four principles because they all keep the same priority. Each principle was quantified by four indicators, equally valuable (6.25\% maximum value). Finally, each variable was assessed as explained in Table 2.

Table 2. Principles, indicators, and variables of SITA.

\begin{tabular}{|c|c|c|c|c|}
\hline Dimension & $\begin{array}{l}\text { Weighted } \\
\text { Principle * }\end{array}$ & $\begin{array}{l}\text { Weighted } \\
\text { Indicator ** }\end{array}$ & Number of Variables Per Indicator & Weighted Variable $* * *$ \\
\hline \multirow{3}{*}{$\begin{array}{c}\text { Agri- } \\
\text { environmental }\end{array}$} & \multirow{3}{*}{$\begin{array}{l}\text { Diversity- } \\
\text { Resilience }\end{array}$} & $\begin{array}{l}\text { Soil fertility } \\
\text { properties }\end{array}$ & $\begin{array}{l}\text { 1. Absence of rocks in the ground } \\
\text { 2. Absence of exposed roots } \\
\text { 3. } \\
\text { 4. }\end{array}$ & $\begin{array}{c}\text { Binary yes } / \text { no response } \\
6.25 / 4 \text { variables }= \\
1.56 \text { points } \\
(\text { If Yes }=1.56)(\text { If } \mathrm{No}=0)\end{array}$ \\
\hline & & $\begin{array}{l}\text { Agricultural } \\
\text { heterogeneity }\end{array}$ & $\begin{array}{ll}\text { 1. } & \text { Presence of vegetables } \\
\text { 2. } & \text { Presence of aromatic plants } \\
\text { 3. } & \text { Presence of ornamental plants } \\
\text { 4. } & \text { Presence of medicinal plants } \\
\text { 5. } & \text { Presence of fruit trees } \\
\text { 6. } & \text { Presence of milpa }\end{array}$ & $\begin{array}{c}\text { Binary yes } / \text { no response } \\
6.25 / 6 \text { variables }= \\
1.04 \text { points } \\
(\text { If } \text { Yes }=1.04) \\
(\text { If } \mathrm{No}=0)\end{array}$ \\
\hline & & $\begin{array}{l}\text { Linking practices } \\
\text { with the home } \\
\text { garden }\end{array}$ & $\begin{array}{l}\text { 1. Incorporation of organic matter } \\
\text { to the soil } \\
\text { 2. Crops rotation maintenance } \\
\text { 3. Presence of fruit trees between } \\
\text { or surrounding the home garden } \\
\text { 4. Presence of cover crops } \\
\text { 5. Polyculture maintenance } \\
\text { 6. Presence of intercrops based on } \\
\text { 7. Integration of farmyard animals } \\
\text { 8. Fallow with hoe }\end{array}$ & $\begin{array}{c}\text { Binary yes } / \text { no response } \\
6.25 / 8 \text { variables }= \\
0.78 \text { points } \\
(\text { If } Y e s=10.78) \\
(\text { If } \mathrm{No}=0)\end{array}$ \\
\hline
\end{tabular}


Table 2. Cont.

\begin{tabular}{|c|c|c|c|c|}
\hline Dimension & $\begin{array}{l}\text { Weighted } \\
\text { Principle * }\end{array}$ & $\begin{array}{l}\text { Weighted } \\
\text { Indicator ** }\end{array}$ & Number of Variables Per Indicator & Weighted Variable $* * *$ \\
\hline & & Farmyard animals & $\begin{array}{l}\text { Presence of creole animals } \\
\text { Presence of farm animals }\end{array}$ & $\begin{array}{c}\text { Binary yes } / \text { no response } \\
6.25 / 2 \text { variables }= \\
3.12 \text { points } \\
(\text { If } Y e s=13.12) \\
(\text { If } \mathrm{No}=0)\end{array}$ \\
\hline \multirow{4}{*}{ Social } & \multirow{4}{*}{$\begin{array}{l}\text { Self-management- } \\
\text { Autonomy }\end{array}$} & $\begin{array}{c}\text { Family } \\
\text { participation }\end{array}$ & $\begin{array}{l}\text { Extended family } \\
\text { Nuclear family } \\
\text { Single-person family }\end{array}$ & $\begin{array}{c}\text { Relative value } \\
\text { (3 variables) } \\
\text { (Extended family = 6.25: } \\
\text { very much; Nuclear } \\
\text { family = 4.16: much and } \\
\text { Single-person family = } \\
\text { 2.08: low) }\end{array}$ \\
\hline & & $\begin{array}{l}\text { Non-acquisition of } \\
\text { external inputs }\end{array}$ & $\begin{array}{l}\text { 1. Non-acquisition of seeds } \\
\text { 2. Non-acquisition of fruit trees } \\
\text { 3. Non-acquisition of farmyard } \\
\text { animals } \\
\text { 4. Non-acquisition of vitamins for } \\
\text { animals }\end{array}$ & $\begin{array}{c}\text { Binary yes } / \text { no response } \\
6.25 / 8 \text { variables }= \\
0.78 \text { points } \\
(\text { If } \mathrm{Yes}=0.78) \\
(\text { If } \mathrm{No}=0)\end{array}$ \\
\hline & & $\begin{array}{l}\text { Benefits of the } \\
\text { home garden to the } \\
\text { family }\end{array}$ & 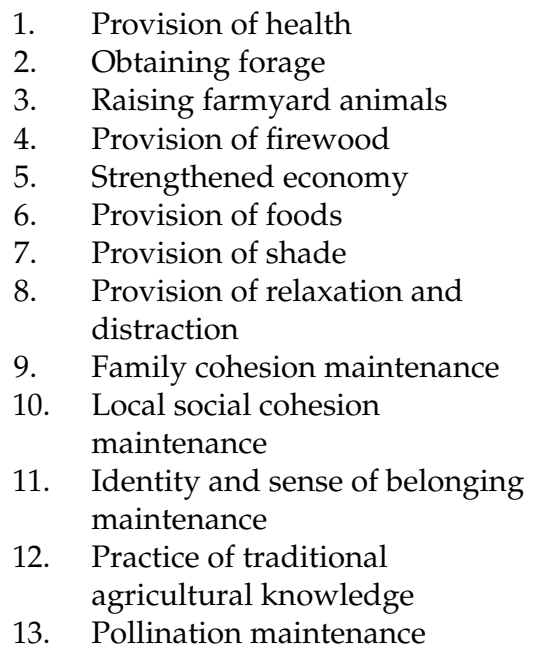 & $\begin{array}{c}\text { Binary yes } / \text { no response } \\
6.25 / 13 \text { variables }= \\
0.48 \text { points } \\
(\text { If } \text { Yes }=0.48) \\
(\text { If } \mathrm{No}=0)\end{array}$ \\
\hline & & $\begin{array}{l}\text { Non-participation } \\
\text { in government } \\
\text { subsidies }\end{array}$ & $\begin{array}{ll}\text { 1. } & \text { No } \\
\text { 2. } & \text { Yes }\end{array}$ & $\begin{array}{c}\text { Relative value } \\
(2 \text { variables }) \\
(\mathrm{No}=6.25 ; \text { Yes }=0)\end{array}$ \\
\hline
\end{tabular}


Table 2. Cont.

\begin{tabular}{|c|c|c|c|c|}
\hline Dimension & $\begin{array}{c}\text { Weighted } \\
\text { Principle * }\end{array}$ & $\begin{array}{l}\text { Weighted } \\
\text { Indicator ** }\end{array}$ & Number of Variables Per Indicator & Weighted Variable $* * *$ \\
\hline \multirow{4}{*}{ Bio-cultural } & \multirow{4}{*}{ Integration } & Local knowledge & 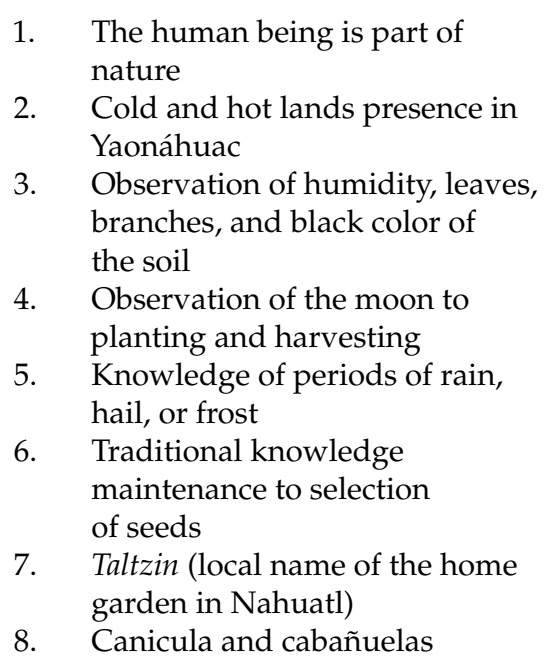 & $\begin{array}{l}\text { Binary yes } / \text { no response } \\
6.25 / 8 \text { variables }= \\
0.78 \text { points } \\
(\text { If } \text { Yes }=0.78) \\
(\text { If } \text { No }=0)\end{array}$ \\
\hline & & Uses of plants & $\begin{array}{ll}\text { 1. } & \text { Food use } \\
\text { 2. } & \text { Ornamental use } \\
\text { 3. } & \text { Medicinal use } \\
\text { 4. } & \text { Presence of living fence } \\
\text { 5. } & \text { Ritual-religious use } \\
\text { 6. } & \text { Firewood use } \\
\text { 7. } & \text { Forage use }\end{array}$ & $\begin{array}{c}\text { Binary yes } / \text { no response } \\
6.25 / 7 \text { variables }= \\
0.89 \text { points } \\
(\text { If } Y e s=10.89) \\
(\text { If } \text { No }=0)\end{array}$ \\
\hline & & $\begin{array}{l}\text { Assuredness of } \\
\text { permanence of the } \\
\text { home garden }\end{array}$ & $\begin{array}{l}\text { 1. Adaptation to the increase in } \\
\text { input prices } \\
\text { 2. Adaptation to illness or death of } \\
\text { a family member } \\
\text { 3. Adaptation to climate changes }\end{array}$ & $\begin{array}{l}\text { Binary yes } / \text { no response } \\
6.25 / 3 \text { variables }= \\
2.08 \text { points } \\
(\text { If } \text { Yes }=2.08) \\
(\text { If } \mathrm{No}=0)\end{array}$ \\
\hline & & $\begin{array}{l}\text { Material type of the } \\
\text { fence or boundary }\end{array}$ & $\begin{array}{ll}\text { 1. } & \text { Living fence } \\
\text { 2. } & \text { Fence of corn cane } \\
\text { 3. } & \text { Artificial fence }\end{array}$ & $\begin{array}{c}\text { Relative value } \\
\text { (3 variables) } \\
\text { (Living fence = 6.25: very } \\
\text { much; fence of corn cane } \\
=4.26: \text { much and, } \\
\text { Artificial fence }=2.08: \\
\text { low) }\end{array}$ \\
\hline Economic & Self-sufficiency & $\begin{array}{l}\text { Productive } \\
\text { diversity }\end{array}$ & $\begin{array}{ll}\text { 1. } & \text { Presence of vegetables } \\
\text { 2. } & \text { Presence of aromatic plants } \\
\text { 3. } & \text { Presence of ornamental plants } \\
\text { 4. } & \text { Presence of medicinal plants } \\
\text { 5. } & \text { Presence of fruit trees } \\
\text { 6. } & \text { Presence of milpa } \\
\text { 7. } & \text { Presence of creole chickens } \\
\text { 8. } & \text { Presence of creole turkeys } \\
\text { 9. } & \text { Presence of creole pigs } \\
\text { 10. } & \text { Presence of farm pigs }\end{array}$ & $\begin{array}{l}\text { Binary yes } / \text { no response } \\
6.25 / 10 \text { variables }= \\
0.62 \text { points } \\
(\text { If Yes }=10.62) \\
(\text { If } \mathrm{No}=0)\end{array}$ \\
\hline
\end{tabular}


Table 2. Cont.

\begin{tabular}{|c|c|c|c|c|}
\hline Dimension & $\begin{array}{l}\text { Weighted } \\
\text { Principle * }\end{array}$ & $\begin{array}{l}\text { Weighted } \\
\text { Indicator ** }\end{array}$ & Number of Variables Per Indicator & Weighted Variable ${ }^{* * *}$ \\
\hline & & Destination of crops & $\begin{array}{ll}\text { 1. } & \text { 1Self-consumption } \\
\text { 2. Sale } \\
\text { 3. Exchange }\end{array}$ & $\begin{array}{c}\text { Binary yes } / \text { no response } \\
6.25 / 3 \text { variables }= \\
2.08 \text { points } \\
(\text { If } \text { Yes }=12.08) \\
(\text { If } \mathrm{No}=0)\end{array}$ \\
\hline & & $\begin{array}{l}\text { Destination of } \\
\text { farmyard animals }\end{array}$ & $\begin{array}{ll}\text { 1. } & \text { Self-consumption } \\
\text { 2. } & \text { Sale } \\
\text { 3. } & \text { Borrowing }\end{array}$ & $\begin{array}{c}\text { Binary yes } / \text { no response } \\
6.25 / 3 \text { variables }= \\
2.08 \text { points } \\
(\text { If } \text { Yes }=12.08) \\
(\text { If } \mathrm{No}=0)\end{array}$ \\
\hline & & $\begin{array}{l}\text { Commercialization } \\
\text { of the home } \\
\text { garden goods }\end{array}$ & $\begin{array}{ll}\text { 1. } & \text { Neighborhood } \\
\text { 2. } & \text { Local } \\
\text { 3. } & \text { Municipal }\end{array}$ & $\begin{array}{c}\text { Binary yes } / \text { no response } \\
6.25 / 3 \text { variables }= \\
2.08 \text { points } \\
(\text { If } \text { Yes }=12.08) \\
(\text { If } \mathrm{No}=0)\end{array}$ \\
\hline
\end{tabular}

Note: * each principle has a score equal to $25,{ }^{* *}$ each indicator has a score equal to 6.25 and ${ }^{* * *}$ each set of variables of an indicator has a different score due to the dissimilar number of variables.

A total of 86 variables were provided by the peasants according to the responses to the in-depth interviews and the participatory field trips. The number of variables considered in each principle were 20 for diversity-resilience, 26 for self-management-autonomy, 21 for integration and 19 for self-sufficiency (Table 2).

The data obtained from the in-depth interviews were processed for the aggregation of the values of each variable according to the following formula:

$$
\mathrm{IND}=\frac{\sum_{i=1}^{n}\left(x_{i}+\cdots+x_{n}\right)}{n}
$$

where:

IND $=$ Any of the 16 indicators

$x=$ Home garden

$n=$ Total number of home gardens (62)

For the interpretation of sustainability, all the values were standardized and transformed to a scale with a range from 0 to 100 , where 0 is the lowest sustainability value and 100 the highest value. The scale was divided into five categories (Table 3).

Table 3. The sustainability scale and its five categories.

\section{Categories}

I. Very weak sustainability $(<20)$

II. Weak sustainability (20.1-40)

III. Intermediate sustainability (40.1-60)

IV. Strong sustainability $(60.1-80)$

V. Super strong sustainability (80.1-100)

\section{Agroecosystem Description}

In critical condition due to the minimal contribution of sustainable activities and practices, where no indicator of sustainability is visible. An instrumental value predominates

Its greater proportion is managed with conventional activities, but some sustainable characteristics appear. An instrumental value predominates.

If sustainable practices are increased it can subsist and stop being vulnerable, but if they decrease it becomes fragile or weak. An anthropocentric perspective predominates.

Where there are sustainable practices and is on the way to sustainable reproduction. It is considered that sustainable practices have been adopted in these, diversifying activities that promote sustainability. An anthropocentric perspective predominates.

With sustainable activities and practices; with a positive impact on the environment and society. It is ideal for maintaining, replicating, and augmenting. A variety of values, plurality of knowledge and a biocentric perspective predominate. 
The results were represented in bar and radar graphs. The principles were analyzed individually and globally. The analysis of the principles of sustainability made it possible to identify the indicators that contributed to reducing or increasing sustainability.

\section{Results and Discussion}

The results are shown as part of a case study of Nahua home gardens in Puebla, Mexico.

\subsection{Diversity-Resilience}

To obtain information about the soil, beyond what is conventional, it is advisable to consider the experience and knowledge of the peasants [52]. In that sense, the indicator related to the soil revealed information on the local perception of families about its fertility properties, whose health is the basis for a "good harvest". In total, $87.1 \%$ of the home gardens had an absence of rocks, an absence of exposed roots, the presence of earthworms and had a soil with a porous texture. Keeping these properties in the soil is important due to the connection between the soil and the human being; human health depends on the health of plants and soil [53]. In addition, good soil management represents a strategy to improve the production and resilience of the agroecosystem, and this strategy is related to food security $[54,55]$.

Another important indicator is agricultural heterogeneity. In $83.9 \%$ of the home gardens there were six types of crops: vegetables, aromatic plants, ornamental plants, medicinal plants, fruit trees and milpa; only $16.1 \%$ did not have a milpa. This plant diversity is relevant because it fosters nutrient-enriching plants, predatory insects, pollinators, nitrogen-fixing and decomposing bacteria, and other organisms that perform various beneficial ecological functions [7]. In addition, a diverse and complex compound of plants can reduce the vulnerability of the agroecosystem to extreme climatic events [56] and provide environmental health and human well-being [57].

Regarding the linking practices with the home garden, it was found that in $72.6 \%$ of the home gardens, the families incorporated organic matter into the soil, carried out crop rotation, had trees in the boundary and between the home garden, they ensured cover crops, polycultures, intercrops based on legumes, integrated farmyard animals and the fallow was carried out with a hoe, which presumes the existence of diverse species of plants that increase biological activity in the home garden. Such diversity of practices helps the traditional agroecosystem to suffer less damage in the presence of hurricanes (compared to conventional monocultures) and reduces its vulnerability to climate variability $[6,31,55]$.

Concerning the farmyard animals' indicator, in $35.5 \%$ of the home gardens, the families had both creole and farm animals, while in $58.1 \%$ they only had creole animals, mainly poultry or pigs, which they used for food or festivities. In $6.5 \%$ they did not have farmyard animals. According to Tremblay et al. [58], the decision of the type and quantity of animal species used as food is associated with a cultural value, which is based on local availability. On the other hand, the incorporation of different components in an agricultural system can improve its yield and reinforce its resilience [59].

Soil fertility, agricultural heterogeneity, and linking practices with the home garden were the indicators with the highest value; only $24.5 \%$ of the home gardens reached the maximum value (Figure 2). 


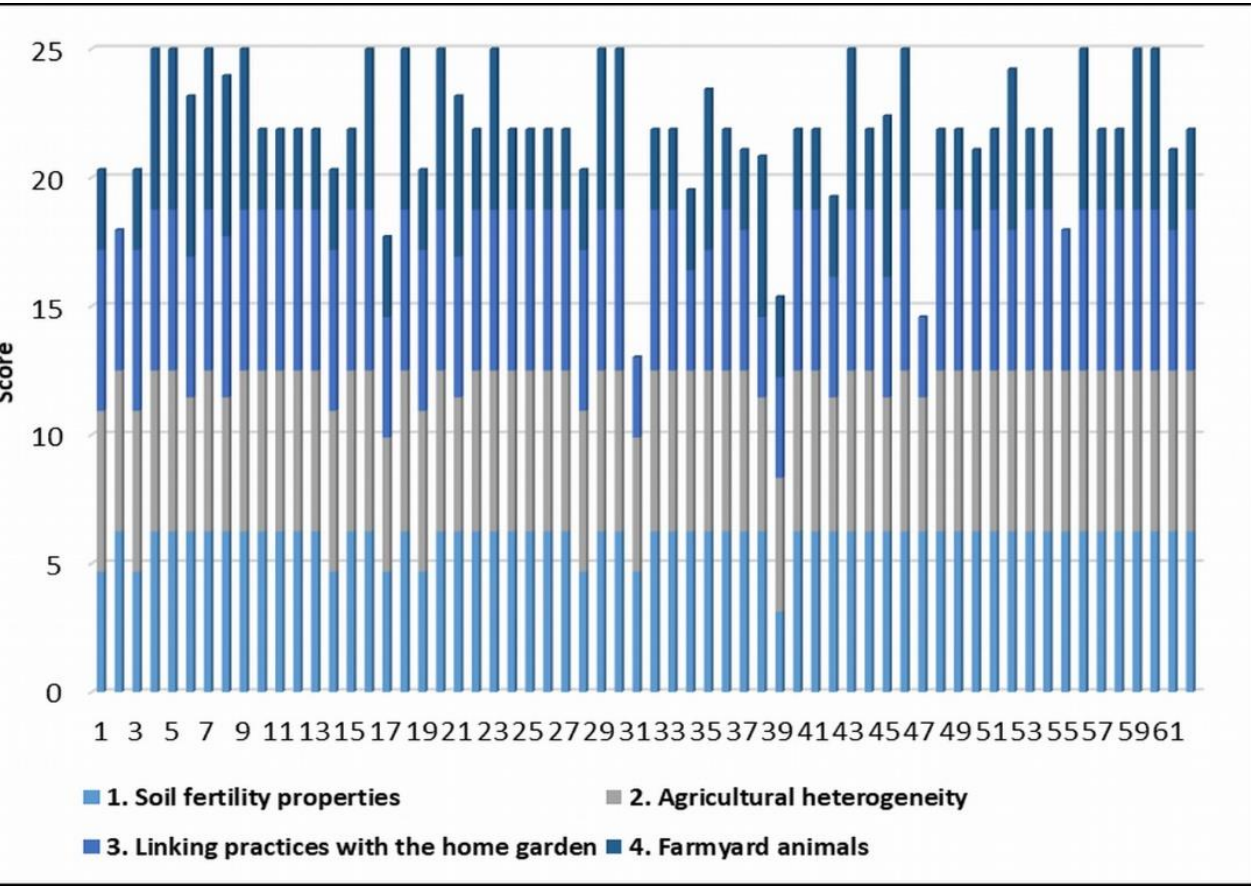

Figure 2. Accumulated value per home garden for the diversity-resilience indicators.

\subsection{Self-Management-Autonomy}

In the indicator family participation, the results showed that $48.4 \%$ of the home gardens were managed by extended families; $41.9 \%$ by nuclear families and $9.7 \%$ by singleperson families, where the availability of workforce decreased considerably. The presence of more members in the family means a greater transmission of knowledge and greater access to workforce. In both extended and nuclear families, the organization of activities for the management of the home garden was carried out according to age, sex and the strength required. This is similar to the finding of Avilez et al. [29] where families distribute their activities according to the capacities of their members.

A low use of external inputs was found in home gardens; $6.5 \%$ of the families did not buy a single input; $21 \%$ purchased two, and $8.5 \%$ purchased only one. However, $4.8 \%$ of the families acquired up to seven of the eight inputs contemplated. This is relevant since the use of external products is not promoted; technological independence and greater control over disturbances are kept. The peasants base the operation of the home gardens on local resources and traditional agroecological techniques, so the use of agrochemicals is reduced and benefits are achieved in terms of low environmental impact and economic advantages due to the reduction in production costs [7,9].

The result of the benefits provided by the home garden (provision of health, provision of fuel, obtaining forage, raising animals, strengthened economy, obtaining food, shade, relaxation and distraction, family cohesion, local social cohesion, identity and sense of belonging, practice of agricultural knowledge or pollination) showed that $12.9 \%$ of the families recognized the total benefits contemplated, while $25.8 \%$ recognized 12 out of 13 and $24.2 \% 11$ out of 13 . These data coincide with Avilez et al. [29], who confirmed that home gardens reinforce the identity and family and neighborhood cohesion, offer aesthetics benefits and transmission of knowledge, favors food sovereignty and care for domestic animals, provides income, wood, medicinal plants, and temperature regulation; it also contributes to local and regional food autonomy by reducing daily expenses.

The management of the home garden is autonomous whenever government subsidies are not implemented. The results show that $77.4 \%$ of the families have not received any subsidy in the last ten years. This reflects that families manage their home garden based only on their own knowledge and on their family workforce, which allows them to make decisions according to their priorities. This is relevant since they remain outside the 
conventional agriculture. Anderson et al. [35] explain that the subsidy encourages the imposition of agricultural packages that lead to economic, technological dependence and external inputs, which severely damage the autonomy of families. In this sense, Altieri [1] and Giraldo and Rosset [60] propose that subsidies should be dismantled to avoid corporate control over food systems and to progress in the scaling of agroecology.

Family participation and non-participation in subsidies were the best represented indicators; no home garden reached the maximum value (Figure 3).

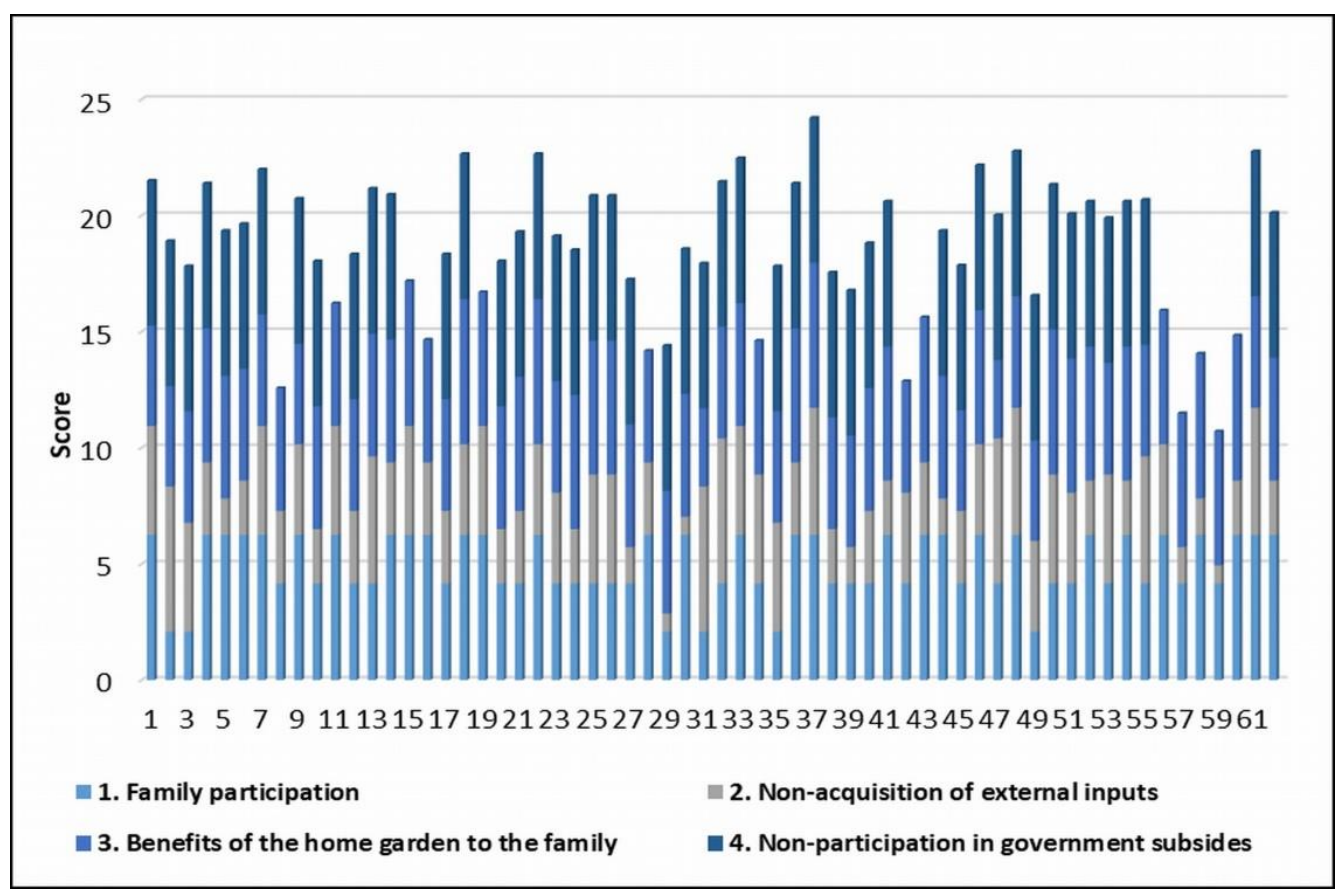

Figure 3. Accumulated value per home garden for the self-management-autonomy indicators.

\subsection{Integration}

With the indicator local knowledge, it was found that $38.7 \%$ of the families recognize the total knowledge contemplated (the human being is part of nature; hot and cold earth; observation of humidity, leaves, branches and black color of the soil; observation of the moon to plant and to harvest; knowledge of the periods of rain, hail or frost; the traditional selection of seeds; Taltzin-local name of the home garden in Nahuatl language-and canicula and cabañuelas); another 32.3\% recognized seven of the eight pieces of knowledge. According to Barrera-Bassols and Toledo [36] this is part of the belief and knowledge system about the local environment. In this regard, Barrera-Bassols et al. [53] suggest paying attention not only to local knowledge and management, but also to the belief system and symbols of the environment. For instance, Fagúndez and Izco [61] concluded that the diversity of phyto-toponyms is related to biodiversity and culture and that it represents intangible cultural heritage. However, as the cultural and linguistic diversity decreases, the biological diversity also decreases; thus, Vidal and Brusca [23] recommended that government resources and efforts be focused on protecting the traditional and cultural knowledge of peasant families.

The indicator uses of plants showed that $83.9 \%$ of the families gave the plants a total of seven uses (food, ornamental or aesthetic, medicinal, living fence, ritual-religious, fuel and forage); $9.7 \%$ of the families recognized six uses, while $3.2 \%$ recognized five of the seven uses. These uses were similar to those reported by Avilez-López et al. [29] who divided the plants according to their use: medicinal, for agricultural production, domestic and other uses (trees for shading, honey plants, to treat insects stings and as oil suppliers). On their side, Zhang et al. [28] reported up to fourteen categories of use (fruits, ornamental plants, 
ritual plants, grain, wood, winemaking, tissue, dyeing plants, vegetables, forage plants, spices, medicines, oilseeds plants and others).

Regarding the assuredness of the permanence of the home garden, only one family said that they adapt to the increase in prices and to climate change, and that they can face illness or death of a relative. A total of $85.5 \%$ of the families adapted to two of the three risks considered and $12.9 \%$ of the families adapted to only one. This confirms what is specified by the IPCC [62], where it is explained that the risks are mainly related to economic, health and meteorological events over which families have no control and which can severely impact them, putting both the agroecosystem and the family members in a vulnerable situation.

In the indicator material of the fence or boundary, it was found that $95.2 \%$ of the home gardens were delimited with a living fence. A total of $3.2 \%$ with artificial fence (wire or mesh) and $1.6 \%$ of the home gardens were delimited with a fence of corn cane. This delimitation with a living fence can be explained in economic terms; an artificial fence is difficult to access economically because of the cost involved. On the other hand, culturally there are bonds of trust and respect for the neighboring spaces and properties, and they prefer to take advantage of and make optimal use of space. According to Nicholls et al. [9] living fences are a management strategy that contributes to reinforcing the functional diversity and the creation of habitats; for instance, it favors soil conditions for plant growth, organic matter management and promotes key ecological services and processes for resilience in the home garden.

The agricultural local knowledges, the uses of plants and the material of the fence or boundary were the indicators with the highest value; no home garden reached the maximum value (Figure 4).

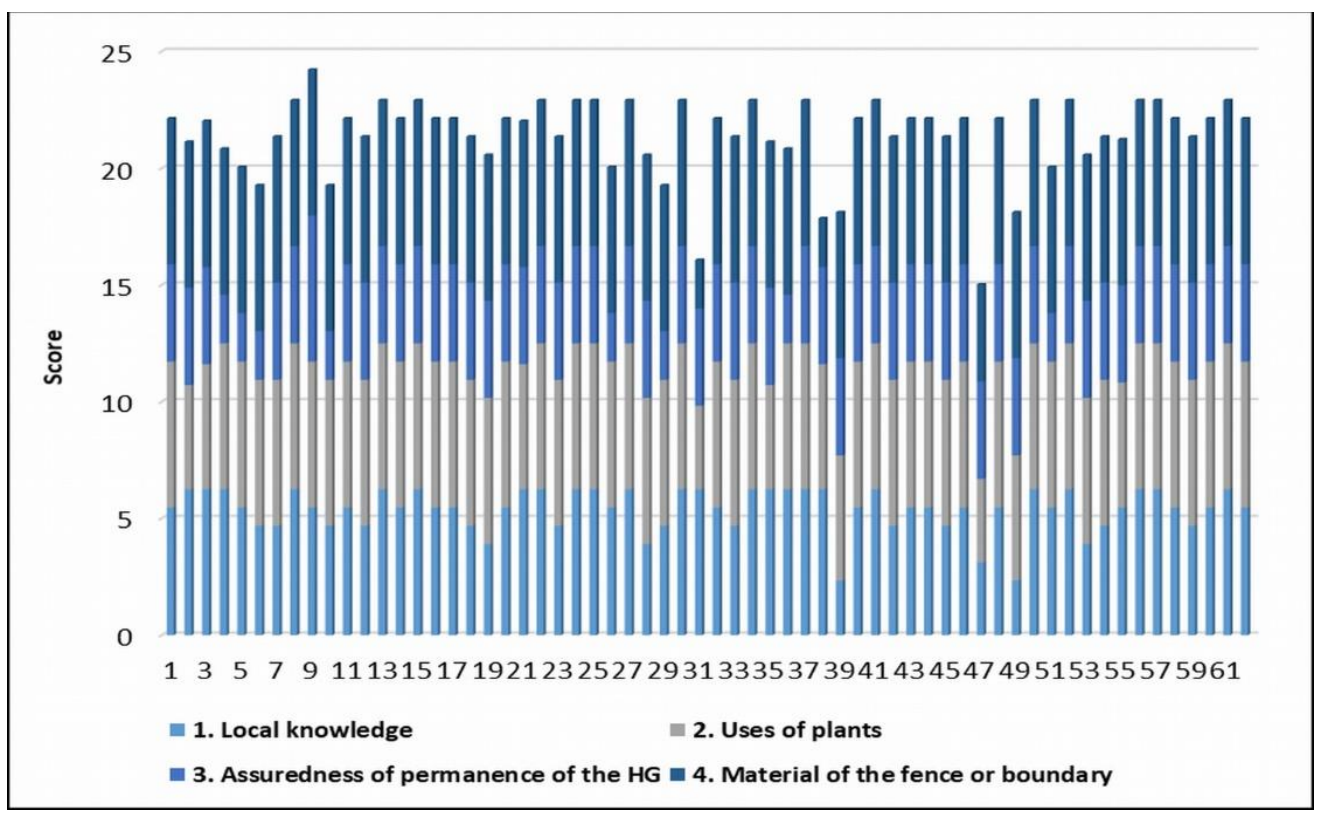

Figure 4. Accumulated value per home garden for the integration indicators.

\subsection{Self-Sufficiency}

The result of the productive diversity showed that in $32.3 \%$ of the home gardens there were ten productive elements (vegetables, aromatic, ornamental, medicinal plants, fruit trees, milpa, creole roosters, creole turkeys, creole pigs and farm pigs); in $27.4 \%$ there were eight and in $29 \%$ there were seven out of 10 . From the perspective of the families, their preference for growing both plants and animals was based on having access to a better diet and a higher income when they were sold. According to Dumont et al. [59], the combination of plants and animals can increase productivity and the efficient use of 
resources. On another side, Altieri and Toledo, Altieri et al. and Segnon et al. $[6,7,63]$ explained that integrated agricultural systems are more productive if total production is considered instead of the yield of a single crop.

The indicator destination of the crops revealed that in $45.2 \%$ of the home gardens the crops were for self-consumption, sale and exchange (barter); while in 38.7\% the crops were sent to two of the three destinations and in $16.1 \%$ they were reserved only for selfconsumption. Toledo et al. and Toledo and Moguel [12,20] explain that families are immersed in a dual economy, because they produce goods for sale and this allows them to obtain manufactured products and other supply products, but at the same time they produce basic goods for their own subsistence. For this reason, they increase the diversity of elements in the home garden. Under these terms, the data become relevant, since the access and availability of food is achieved through subsistence agriculture, which reinforces family self-sufficiency [26].

Regarding the destination of the farmyard animals, it was found that in $46.8 \%$ of the home gardens, the farmyard animals were for self-consumption, sale and borrowing; in $32.3 \%$ the animals were reserved for two of the three destinations and in $14.5 \%$ of the home gardens they were only available for self-consumption. The borrowing of animals between relatives or neighbors represents the predominance of an important cultural activity that helps to maintain harmony between families and communities. It consists of knowing the exact weight of the animal, generally poultry, so that it is returned in the same conditions, in a period that can go from three to five years. According to Anderson et al. [35], this exchange is accessible, fair, profitable, and satisfactory for the families involved in this process; this makes it part of a traditional system of exchange of goods which is in a small volume and locally adapted.

Finally, the commercialization of home garden goods was carried out at the neighborhood, local and municipal level in $30.6 \%$ of the home gardens, while in $50 \%$ of them, it was carried out in one of the three types of commercialization (neighborhood or local) and in $19.4 \%$ of the home gardens no type of commercialization was carried out. The commercialized goods reached different municipalities (Atempan, Tlatlauquitepec, Teziutlán and Zacapoaxtla), this suggests significant economic mobility through the marketing channels through which the same families sought to reach diverse consumers. Toledo and Moguel and Anderson et al. [12,35] stated that mobility of goods in various market niches offers a form of production that allows the local accumulation of wealth and is opposed to a global accumulation dominated by specialization and short-term performance maximization. In addition, local and municipal marketing was carried out through the so-called "Tianguis" or street markets; the Nahuatl terms refer to traditional local markets where producers from neighboring municipalities come to market or exchange (barter) their agricultural or animal goods and thus diversify their income. Moreover, due to its permanence in time, it goes beyond the alternative tianguis reported by Toledo and Barrera-Bassols [19], since they sell certified products or not from agroecological or ecological producers.

The productive diversity and the destination of the crops were the indicators with the highest value; no home garden reached the maximum value (Figure 5). 


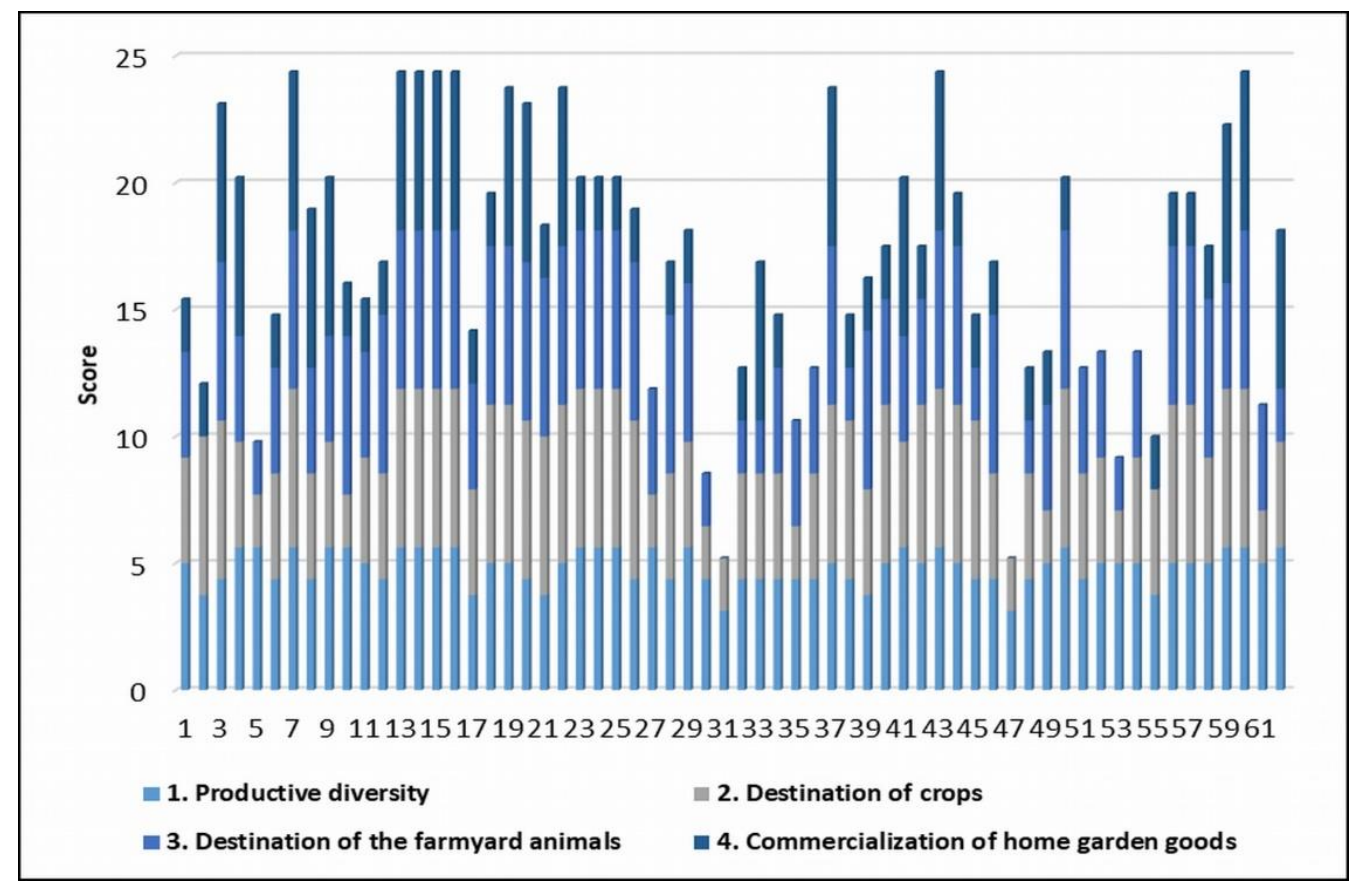

Figure 5. Accumulated value per home garden for the self-sufficiency indicators.

\subsection{Sustainability of Nahua Home Gardens in the High Region of Yaonáhuac, Puebla}

Based on the categories in Table 3, the results showed that very weak sustainability and weak sustainability were not represented in the study area, while intermediate, strong, and super strong sustainability did find representation (Table 4).

Table 4. Home garden's values of diversity-resilience, self-management-autonomy, integration, and self-sufficiency of SITA.

\begin{tabular}{|c|c|c|c|c|c|c|c|}
\hline Home Garden & Size $\left(\mathrm{m}^{2}\right)$ & $\begin{array}{l}\text { Diversity- } \\
\text { Resilience } \\
\text { (25) }\end{array}$ & $\begin{array}{c}\text { Self-Management- } \\
\text { Autonomy } \\
\text { (25) }\end{array}$ & $\begin{array}{c}\text { Integration } \\
(25)\end{array}$ & $\begin{array}{c}\text { Self- } \\
\text { Sufficiency } \\
(25)\end{array}$ & SITA & Category \\
\hline 1 & 937 & 20.3 & 21.5 & 22.1 & 15.4 & 79.4 & IV \\
\hline 2 & 394 & 18.0 & 18.9 & 21.1 & 12.1 & 70.1 & IV \\
\hline 3 & 186 & 20.3 & 17.8 & 22.0 & 23.1 & 83.3 & $\mathrm{~V}$ \\
\hline 4 & 426 & 25.0 & 21.4 & 20.8 & 20.2 & 87.4 & $\mathrm{~V}$ \\
\hline 5 & 643 & 25.0 & 19.4 & 20.1 & 9.8 & 74.2 & IV \\
\hline 6 & 935 & 23.2 & 19.7 & 19.3 & 14.8 & 76.9 & IV \\
\hline 7 & 1292 & 25.0 & 22.0 & 21.4 & 24.4 & 92.7 & V \\
\hline 8 & 339 & 24.0 & 12.6 & 22.9 & 19.0 & 78.4 & IV \\
\hline 9 & 564 & 25.0 & 20.7 & 24.2 & 20.2 & 90.2 & $\mathrm{~V}$ \\
\hline 10 & 195 & 21.9 & 18.0 & 19.3 & 16.0 & 75.2 & IV \\
\hline 11 & 1040 & 21.9 & 16.2 & 22.1 & 15.4 & 75.7 & IV \\
\hline 12 & 531 & 21.9 & 18.3 & 21.4 & 16.9 & 78.4 & IV \\
\hline 13 & 461 & 21.9 & 21.2 & 22.9 & 24.4 & 90.3 & V \\
\hline 14 & 472 & 20.3 & 20.9 & 22.1 & 24.4 & 87.7 & V \\
\hline 15 & 825 & 21.9 & 17.2 & 22.9 & 24.4 & 86.4 & V \\
\hline 16 & 472 & 25.0 & 14.7 & 22.1 & 24.4 & 86.2 & V \\
\hline 17 & 314 & 17.7 & 18.3 & 22.1 & 14.2 & 72.4 & IV \\
\hline 18 & 513 & 25.0 & 22.7 & 21.4 & 19.6 & 88.6 & $\mathrm{~V}$ \\
\hline 19 & 532 & 20.3 & 16.7 & 20.6 & 23.8 & 81.3 & V \\
\hline 20 & 664 & 25.0 & 18.0 & 22.1 & 23.1 & 88.3 & V \\
\hline
\end{tabular}


Table 4. Cont.

\begin{tabular}{|c|c|c|c|c|c|c|c|}
\hline Home Garden & Size $\left(\mathrm{m}^{2}\right)$ & $\begin{array}{l}\text { Diversity- } \\
\text { Resilience } \\
\quad(25)\end{array}$ & $\begin{array}{c}\text { Self-Management- } \\
\text { Autonomy } \\
(25)\end{array}$ & $\begin{array}{c}\text { Integration } \\
(25)\end{array}$ & $\begin{array}{c}\text { Self- } \\
\text { Sufficiency } \\
(25)\end{array}$ & SITA & Category \\
\hline 21 & 356 & 23.2 & 19.3 & 22.0 & 18.3 & 82.8 & V \\
\hline 22 & 748 & 21.9 & 22.7 & 22.9 & 23.8 & 91.2 & $\mathrm{~V}$ \\
\hline 23 & 205 & 25.0 & 19.1 & 21.4 & 20.2 & 85.7 & V \\
\hline 24 & 273 & 21.9 & 18.5 & 22.9 & 20.2 & 83.5 & V \\
\hline 25 & 416 & 21.9 & 20.9 & 22.9 & 20.2 & 85.9 & V \\
\hline 26 & 652 & 21.9 & 20.9 & 20.1 & 19.0 & 81.8 & V \\
\hline 27 & 133 & 21.9 & 17.3 & 22.9 & 11.9 & 73.9 & IV \\
\hline 28 & 213 & 20.3 & 14.2 & 20.6 & 16.9 & 71.9 & IV \\
\hline 29 & 187 & 25.0 & 14.4 & 19.3 & 18.1 & 76.8 & IV \\
\hline 30 & 241 & 25.0 & 18.6 & 22.9 & 8.5 & 75.0 & IV \\
\hline 31 & 79 & 13.0 & 17.9 & 16.1 & 5.2 & 52.2 & III \\
\hline 32 & 892 & 21.9 & 21.5 & 22.1 & 12.7 & 78.2 & IV \\
\hline 33 & 917 & 21.9 & 22.5 & 21.4 & 16.9 & 82.6 & $\mathrm{~V}$ \\
\hline 34 & 281 & 19.5 & 14.6 & 22.9 & 14.8 & 71.9 & IV \\
\hline 35 & 414 & 23.4 & 17.8 & 21.1 & 10.6 & 73.0 & IV \\
\hline 36 & 973 & 21.9 & 21.4 & 20.8 & 12.7 & 76.8 & IV \\
\hline 37 & 747 & 21.1 & 24.2 & 22.9 & 23.8 & 92.0 & V \\
\hline 38 & 306 & 20.8 & 17.6 & 17.9 & 14.8 & 71.0 & IV \\
\hline 39 & 182 & 15.4 & 16.8 & 18.1 & 16.3 & 66.5 & IV \\
\hline 40 & 180 & 21.9 & 18.8 & 22.1 & 17.5 & 80.3 & $\mathrm{~V}$ \\
\hline 41 & 394 & 21.9 & 20.6 & 22.9 & 20.2 & 85.6 & $\mathrm{~V}$ \\
\hline 42 & 420 & 19.3 & 12.9 & 21.4 & 17.5 & 71.0 & IV \\
\hline 43 & 853 & 25.0 & 15.6 & 22.1 & 24.4 & 87.1 & $\mathrm{~V}$ \\
\hline 44 & 485 & 21.9 & 19.4 & 22.1 & 19.6 & 82.9 & $\mathrm{~V}$ \\
\hline 45 & 102 & 22.4 & 17.9 & 21.4 & 14.8 & 76.4 & IV \\
\hline 46 & 1022 & 25.0 & 22.2 & 22.1 & 16.9 & 86.2 & $\mathrm{~V}$ \\
\hline 47 & 133 & 14.6 & 20.0 & 15.0 & 5.2 & 54.8 & III \\
\hline 48 & 220 & 21.9 & 22.8 & 22.1 & 12.7 & 79.5 & IV \\
\hline 49 & 397 & 21.9 & 16.6 & 18.1 & 13.3 & 69.9 & IV \\
\hline 50 & 605 & 21.1 & 21.3 & 22.9 & 20.2 & 85.6 & $\mathrm{~V}$ \\
\hline 51 & 645 & 21.9 & 20.1 & 20.1 & 12.7 & 74.7 & IV \\
\hline 52 & 623 & 24.2 & 20.6 & 22.9 & 13.3 & 81.1 & $\mathrm{~V}$ \\
\hline 53 & 287 & 21.9 & 19.9 & 20.6 & 9.2 & 71.5 & IV \\
\hline 54 & 285 & 21.9 & 20.6 & 21.4 & 13.3 & 77.2 & IV \\
\hline 55 & 429 & 18.0 & 20.7 & 21.2 & 10.0 & 69.9 & IV \\
\hline 56 & 610 & 25.0 & 15.9 & 22.9 & 19.6 & 83.4 & $\mathrm{~V}$ \\
\hline 57 & 933 & 21.9 & 11.5 & 22.9 & 19.6 & 75.9 & IV \\
\hline 58 & 710 & 21.9 & 14.1 & 22.1 & 17.5 & 75.6 & IV \\
\hline 59 & 762 & 25.0 & 10.7 & 21.4 & 22.3 & 79.4 & IV \\
\hline 60 & 685 & 25.0 & 14.8 & 22.1 & 24.4 & 86.4 & $\mathrm{~V}$ \\
\hline 61 & 422 & 21.1 & 22.8 & 22.9 & 11.3 & 78.0 & IV \\
\hline 62 & 272 & 21.9 & 20.1 & 22.1 & 18.1 & 82.3 & $\mathrm{~V}$ \\
\hline
\end{tabular}

\subsubsection{Home Gardens with Intermediate Sustainability}

Two home gardens (31 and 47) were found with a SITA of 57.3 and 54.8 each. The Diversity-Resilience indicators had discontinuous values, because one home garden had non-porous soil; the two families did not have milpa and had only four out of eight linking practices with their home garden, in addition, the two families did not have creole or farm animals. Self-sufficiency was affected in a very severe way because in both home gardens there was no commercialization of the home garden goods, in addition, they had only five of the 10 variables considered for productive diversity, and the destination of the crops was for family consumption.

Regarding Self-Management-Autonomy and assuredness of permanence of the home garden, it is important to note that the first home garden was operated by a 94-year-old 
widower peasant, for whom the lack of close relatives to support him puts the home garden in a vulnerable situation in case the peasant falls ill. The second home garden was operated by a nuclear family, where there was less risk in the permanence of the home garden. These family types (single-person and nuclear family) did not acquire a single external input, nor did they participate in any subsidy, for this reason the peak of these two indicators reached their maximum average value. This principle diminished because the two families visualized only seven of the 13 benefits of the home garden.

The indicators with a continuous value were those of Integration; the same peasant is acquainted with the local agricultural knowledge, since he gave a nutritional, ornamental, medicinal and ritual-religious use to his agricultural goods. On their side, the nuclear family gave the plants a nutritional, ornamental, living fence and ritual-religious use (Figure 6).

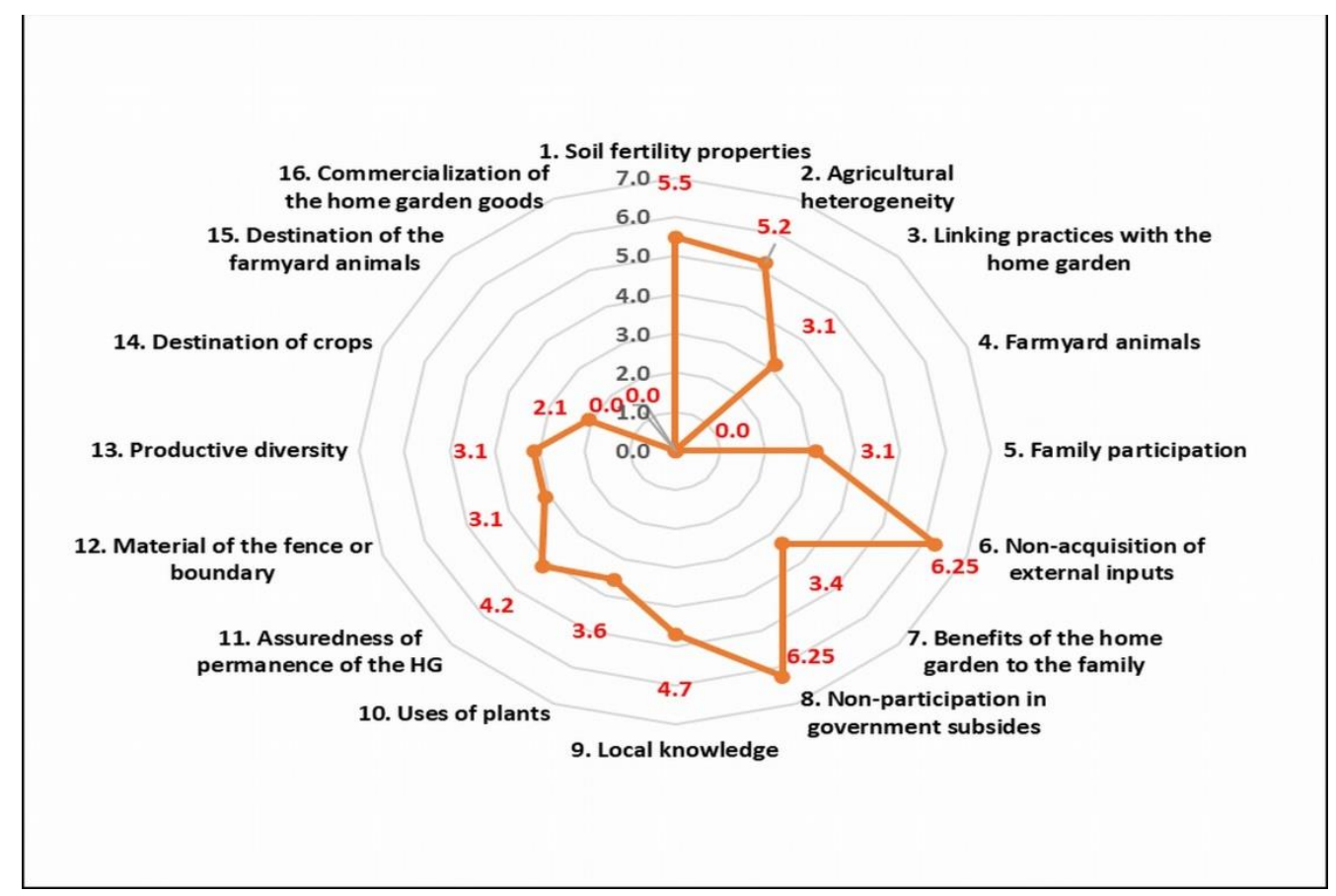

Figure 6. Average value per indicator of home gardens with intermediate sustainability.

\subsubsection{Home Gardens with Strong Sustainability}

In total, 31 home gardens were found with an average SITA of 74.7. All the indicators had participation, none fell to zero, but they did not reach a maximum value. The DiversityResilience value was low because two of the 31 families did not have creole or farm animals. On their side, eight of the 31 families had participated in government subsidies in the last 10 years, which affected their Self-Management-Autonomy. Integration indicators were better represented; however, six of the 31 families found it difficult to adapt to the increase in the prices of inputs and to illness or death of a relative. Two families did not have farmyard animals and did not have commercial activity, adding to the nine families that did not commercialize crops or animals, which reduced their self-sufficiency (Figure 7). 


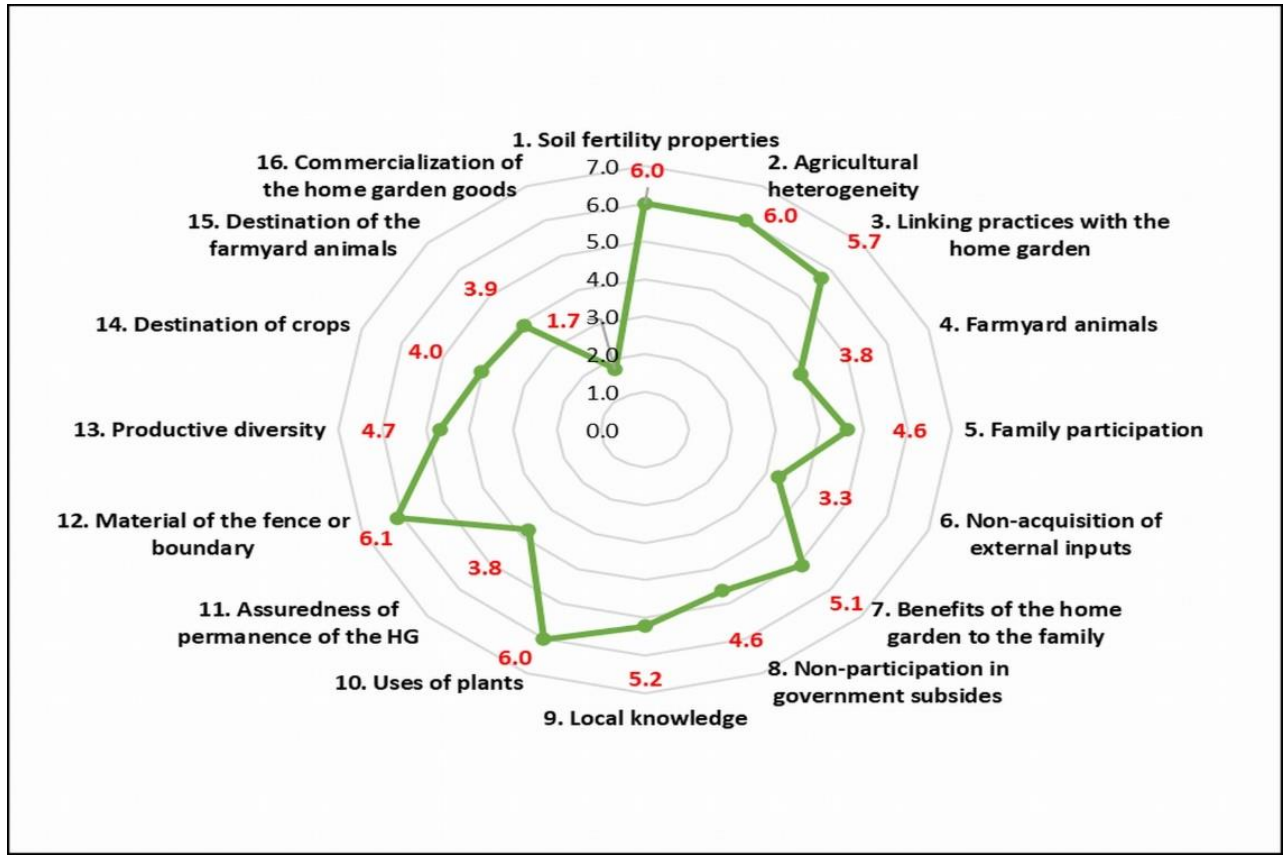

Figure 7. Average value per indicator of home gardens with strong sustainability.

\subsubsection{Home Gardens with Super Strong Sustainability}

A total of 29 home gardens were found with an average SITA of 85.8. All the indicators were represented, and none fell to zero. The best represented indicators were DiversityResilience. Self-management-Autonomy had decreasing numbers because six families did participate in a government subsidy. Integration was diminished because only one family stated that they had no difficulty adapting to the increase in input prices, to illness or death of a relative, and to climate changes (generally torrential rains or strong winds). Finally, Self-sufficiency was affected because a family did not commercialize their goods in any way (Figure 8).

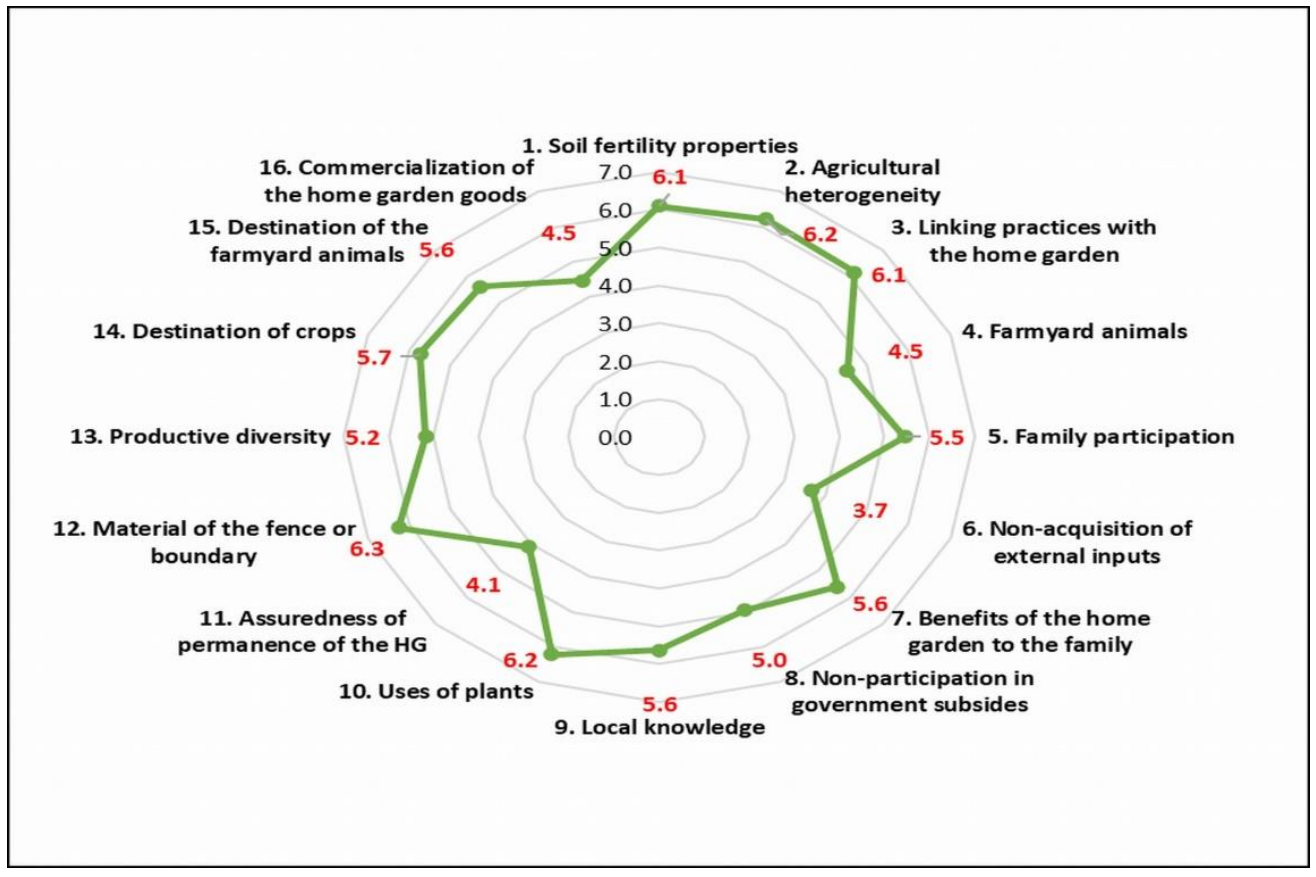

Figure 8. Average value per indicator of home gardens with super strong sustainability. 
As is shown, the Nahua home garden is a traditional agroecosystem that has prevailed even though the environmental and economic instability [6]. The home gardens promote the diversity of the species and their use reflect a strategy to guarantee the availability and accessibility of a varied diet at a home level [26]. The Nahua home garden, seen as a traditional agroecosystem, is a model that provides ecological services and its multifunctionality favors a peasant's lifestyle. Local management of a varied number of crops contributes greatly to family subsistence [12].

\section{Conclusions}

The results revealed that in Nahua home gardens, the Sustainability Index for Traditional Agroecosystems increases with soil fertility, agricultural heterogeneity, linking practices with the home garden, family participation, the benefits of the home garden to the family, the non-participation in government subsidies, agricultural local knowledges, the uses of plants, the material of the fence or boundary, the productive diversity, and the destination of the crops. It was also observed that the indicators, farmyard animals, the non-acquisition of external inputs and the assuredness of permanence of the home garden had a low score. While the most vulnerable indicators were the destination of the farmyard animals and the commercialization of home garden goods, as they fell to zero, the latter placed two home gardens in the intermediate sustainability category. It was found that 31 home gardens had a strong sustainability, in their own way, these families recognized not only an economic value of nature, but also an ecological and cultural value. Another 29 home gardens had a super strong sustainability, which implies that the same number of families recognize a plurality of valuations of nature (ethical, economic, ecological, social, cultural, aesthetic, religious) and an inherent and intrinsic value that does not depend on the utility or appropriation that they give.

The proposal to evaluate the sustainability of a traditional agroecosystem with the principles of diversity-resilience, self-management-autonomy, integration, and self-sufficiency as axes of analysis, supposes a methodological contribution that bets on indicators that better represent the reality of the Nahua home gardens in the high region of Yaonáhuac, Puebla. In addition, the variables were considered according to the perception of the families based on their practice and knowledge which gives SITA an opportunity for both a theoretical and a practical debate. The index can be used to research small-scale traditional agroecosystems with similar characteristics to monitor their sustainability, as well as to assist in decision-making and promote agroecological management from the home.

The results of this research correspond only to a one-year monitoring, and thus there is still much to learn about these traditional agroecosystems. Many efforts have been made to design and apply indices to measure the sustainability of agricultural systems. Peasants, researchers, extension workers, decision makers, public policy makers, among others, require detailed and reliable information on agricultural activities. The applied index is a tool that can provide such information to make the best management decisions or intromission in the study area by the mentioned social actors.

Four dimensions of sustainability (agri-environmental, social, biocultural, and economic), four principles (diversity-resilience, Self-management-autonomy, integration, and self-sufficiency), 16 indicators and 86 variables were considered. This suggests that decision makers and public policy makers on the agricultural sector at the national, state, regional and local levels can use the index to diagnose the sustainability of agroecosystems. In addition, they can focus their efforts on promoting the disuse of synthetic fertilizers and pesticides, encouraging the keeping of poultry animals, and improving commercialization channels.

Integrating a biocultural dimension in sustainability implies considering the knowledge and experience of the peasants, which generates confidence in themselves, their ancestral agricultural practices are valued and the gap between the farming community and the academic community is narrowed. The index can support academic researchers in understanding the state of sustainability of home gardens in the study area, but if applied 
in a broader geographic area, the sustainability of the northeastern region of Puebla, Mexico can be known.

Author Contributions: Conceptualization, M.I.P.-G. and S.E.S.-G.; methodology, M.I.P.-G. and S.E.S.G.; validation, S.E.S.-G. and E.T.; formal analysis, M.I.P.-G. and S.E.S.-G.; investigation, M.I.P.-G.; resources, E.T.; data curation, M.I.P.-G.; writing-original draft preparation, M.I.P.-G.; writingreview and editing, E.T.; supervision, I.C.-C. and L.L.-R. All authors have read and agreed to the published version of the manuscript.

Funding: This research project was funded by the Ph.D. Grant Number 494646 from CONACYT.

Institutional Review Board Statement: Not applicable.

Informed Consent Statement: Informed consent was obtained from all subjects involved in the study.

Acknowledgments: The authors wish to thank to the anonymous informants that received and introduced us to the region of study. Thanks to Posgrado en Ciencias Ambientales, ICUAP and VIEP for the resources granted to carry out the doctoral stay, as well as Juana Aznar Marquez for her valuable support during the doctoral stay at the Universitas Miguel Hernandez. Thanks to Arturo Sánchez Porras for his support in the elaboration of the map.

Conflicts of Interest: The authors declare no conflict of interest. The funders had no role in the design of the study; in the collection, analyses, or interpretation of data; in the writing of the manuscript, or in the decision to publish the results.

\section{References}

1. Altieri, M.A. Agroecology: The science of natural resource management for poor farmers in marginal environments. Agric. Ecosyst. Environ. 2002, 93, 1-24. [CrossRef]

2. Fish, R.; Church, A.; Winter, M. Conceptualising cultural ecosystem services: A novel framework for research and critical engagement. Ecosyst. Serv. 2016, 21, 208-217. [CrossRef]

3. Sabiha, N.-E.; Salim, R.; Rahman, S.; Rola-Rubzen, M.F. Measuring environmental sustainability in agriculture: A composite environmental impact index approach. J. Environ. Manag. 2016, 166, 84-93. [CrossRef] [PubMed]

4. Altieri, M.A.; Koohafkan, P. Enduring Farms: Climate Change, Smallholders and Traditional Farming Communites [Internet]; Third World Network: Penang, Malasya, 2008; pp. 1-72. Available online: http://www.fao.org/nr/water/docs/enduring_farms.pdf (accessed on 15 October 2020).

5. Koohafkan, P.; Altieri, M.A. Sistemas Ingeniosos del Patrimonio Agrícola Mundial: Un Legado Para el Futuro; SIPAM; FAO: Roma, Italy, 2011; p. 47.

6. Altieri, M.A.; Funes-Monzote, F.R.; Petersen, P. Agroecologically efficient agricultural systems for smallholder farmers: Contributions to food sovereignty. Agron. Sustain. Dev. 2012, 32, 1-13. [CrossRef]

7. Altieri, M.A.; Toledo, V.M. The agroecological revolution in Latin America: Rescuing nature, ensuring food sovereignty and empowering peasants. J. Peasant. Stud. 2011, 38, 587-612. [CrossRef]

8. Fernandez, M.; Goodall, K.; Olson, M.; Méndez, V.E. Agroecology and alternative agri-food movements in the United States: To-ward a sustainable agri-food system. Agroecol. Sustain. Food Syst. 2013, 37, 115-126.

9. Nicholls, C.; Altieri, M.; Vazquez, L. Agroecology: Principles for the Conversion and Redesign of Farming Systems. J. Ecosyst. Ecography 2016, 5, 1-18.

10. Reyna-Ramírez, C.A.; Rodríguez-Sánchez, L.M.; Vela-Correa, G.; Etchevers-Barra, J.; Fuentes-Ponce, M. Redesign of the traditional Mesoamerican agroecosystem based on participative ecological intensification: Evaluation of the soil and efficiency of the system. Agric. Syst. 2018, 165, 177-186. [CrossRef]

11. Tittonell, P. Assessing resilience and adaptability in agroecological transitions. Agric. Syst. 2020, 184, 102862. [CrossRef]

12. Toledo, V.M.; Moguel, P. Coffee and Sustainability: The Multiple Values of Traditional Shaded Coffee. J. Sustain. Agric. 2012, 36, 353-377. [CrossRef]

13. Speelman, E.N.; López-Ridaura, S.; Colomer, N.A.; Astier, M.; Masera, O.R. Ten years of sustainability evaluation using the MESMIS framework: Lessons learned from its application in 28 Latin American case studies. Int. J. Sustain. Dev. World Ecol. 2007, 14, 345-361. [CrossRef]

14. Astier, M.; Speelman, E.N.; López-Ridaura, S.; Masera, O.R.; Gonzalez-Esquivel, C.E. Sustainability indicators, alternative strategies and trade-offs in peasant agroecosystems: Analysing 15 case studies from Latin America. Int. J. Agric. Sustain. 2011, 9, 409-422. [CrossRef]

15. Peano, C.; Tecco, N.; Dansero, E.; Girgenti, V.; Sottile, F. Evaluating the sustainability in complex agri-food systems: The SAE-METH ramework. Sustainability 2015, 7, 6721-6741. [CrossRef]

16. Flores, C.C.; Sarandón, S.J. Limitations of Neoclassical Economics for Evaluating Sustainability of Agricultural Systems: Comparing Organic and Conventional Systems. J. Sustain. Agric. 2004, 24, 77-91. [CrossRef] 
17. Boege, E. El Patrimonio Biocultural de los Pueblos Indígenas de México. Hacía la Conservación In Situ de la Biodiversidad y Agrodiversidad en los Territorios Indígenas, Primera ed.; Chan, G.V., Coll, I.G., Mondragón, M., Rivas, A., Lozada, M.P., Soto, F., Eds.; Instituto Nacional de Antropologóa e Historia: Ciudad de México, Mexico; Comisión Nacional para el Desarrollo de los Pueblos Indígenas: Mexico City, Mexico, 2008; p. 344.

18. Bermeo, A.; Couturier, S.; Pizaña, M.G. Conservation of traditional smallholder cultivation systems in indigenous territories: Mapping land availability for milpa cultivation in the Huasteca Poblana, Mexico. Appl. Geogr. 2014, 53, 299-310. [CrossRef]

19. Toledo, V.M.; Barrera-Bassols, N. Political Agroecology in Mexico: A Path toward Sustainability. Sustainability 2017, 9, 268. [CrossRef]

20. Toledo, V.M.; Ortiz-Espejel, B.F.; Cortés, L.; Moguel, P.; Ordoñez, M.D.J. The Multiple Use of Tropical Forests by Indigenous Peoples in Mexico: A Case of Adaptive Management. Conserv. Ecol. 2003, 7. [CrossRef]

21. Darnhofer, I.; Fairweather, J.; Moller, H. Assessing a farm's sustainability: Insights from resilience thinking. Int. J. Agric. Sustain. 2010, 8, 186-198. [CrossRef]

22. Boege, E. Hacia una antropología ambiental para la apropiación social del patrimonio biocultural de los pueblos indígenas en América Latina. Desenvolv. Meio Ambient. 2015, 35, 101-120. [CrossRef]

23. Vidal, O.; Brusca, R.C. Mexico's biocultural diversity in peril. Rev. Biol. Trop. 2020, 68, 669-691. [CrossRef]

24. Altieri, M.A.; Nicholls, C.I. Agroecology: A brief account of its origins and currents of thought in Latin America. Agroecol. Sustain. Food Syst. 2017, 41, 231-237. [CrossRef]

25. Lappé, F.M. Farming for a Small Planet: Agroecology Now. Development 2016, 59, 299-307. [CrossRef]

26. Rankoana, S.A. Subsistence Food Production Practices: An Approach to Food Security and Good Health. Int. J. Environ. Res. Public Health 2017, 14, 1184. [CrossRef] [PubMed]

27. Singh, R.K.; Kumar, A.; Singh, A.; Singhal, P. Evidence that cultural food practices of Adi women in Arunachal Pradesh, India, improve social-ecological resilience: Insights for Sustainable Development Goals. Ecol. Process. 2020, 9, 1-19. [CrossRef]

28. Zhang, Y.; Yang, L.-X.; Li, M.-X.; Guo, Y.-J.; Li, S.; Wang, Y.-H. The best choices: The diversity and functions of the plants in the home gardens of the Tsang-la (Motuo Menba) communities in Yarlung Tsangpo Grand Canyon, Southwest China. J. Ethnobiol. Ethnomed. 2020, 16, 1-15. [CrossRef]

29. Avilez-López, T.; Van Der Wal, H.; Aldasoro-Maya, E.M.; Rodríguez-Robles, U. Home gardens' agrobiodiversity and owners' knowledge of their ecological, economic and socio-cultural multifunctionality: A case study in the lowlands of Tabasco, México. J. Ethnobiol. Ethnomed. 2020, 16, 1-13. [CrossRef]

30. La Vía Campesina. Sustainable Peasant and Family Farm Can Feed the World. Via Campesina Views [Internet]. 2010. Available online: https:/ /viacampesina.org/downloads/pdf/en/paper6-EN-FINAL.pdf (accessed on 14 October 2020).

31. Altieri, M.A.; Nicholls, C.I.; Henao, A.; Lana, M.A. Agroecology and the design of climate change-resilient farming systems. Agron. Sustain. Dev. 2015, 35, 869-890. [CrossRef]

32. Groot, J.C.J.; Cortez-Arriola, J.; Rossing, W.A.H.; Massiotti, R.D.A.; Tittonell, P. Capturing Agroecosystem Vulnerability and Resilience. Sustainability 2016, 8, 1206. [CrossRef]

33. Marten, G. Productivity, Stability, Sustainability, Equitability and Autonomy as Properties for Agroecosystem Assessment. Agric. Syst. 1988, 26, 291-316. Available online: http:/ / www.gerrymarten.com/publicatons/agroecosystem-Assessment.html (accessed on 7 February 2017). [CrossRef]

34. Šūmane, S.; Kunda, I.; Knickel, K.; Strauss, A.; Tisenkopfs, T.; des los Rios, I.; Rivera, M.; Chebach, T.; Ashkenazy, A. Local and farmers' knowledge matters! How inte-grating informal and formal knowledge enhances sustainable and resilient agriculture. J. Rural Stud. 2018, 59, 232-241. [CrossRef]

35. Anderson, C.R.; Bruil, J.; Chappell, M.J.; Kiss, C.; Pimbert, M.P. From Transition to Domains of Transformation: Getting to Sustaina-ble and Just Food Systems through Agroecology. Sustainability 2019, 11, 5272. [CrossRef]

36. Barrera-Bassols, N.; Toledo, V.M. Ethnoecology of the Yucatec Maya: Symbolism, knowledge and management of natural re-sources. J. Lat. Am. Geogr. 2005, 4, 9-41. [CrossRef]

37. Toledo, V.M. Indigenous Peoples and Biodiversity. Encycl. Biodivers. 2013, 4, 269-278.

38. De Roest, K.; Ferrari, P.; Knickel, K. Specialisation and economies of scale or diversification and economies of scope? Assessing different agricultural development pathways. J. Rural Stud. 2018, 59, 222-231. [CrossRef]

39. Shmelev, S.E.; Rodríguez-Labajos, B. Dynamic multidimensional assessment of sustainability at the macro level: The case of Austria. Ecol. Econ. 2009, 68, 2560-2573. [CrossRef]

40. Gudynas, E. Desarrollo y sustentabilidad ambiental: Diversidad de posturas, tensiones persistentes. In La Tierra no es Muda: Diálogos Entre el Desarrollo Sostenible y el Postdesarrollo; Matarán Ruíz, A., López Castellano, F., Eds.; Universidad de Granada: Granada, Spain, 2011; pp. 69-96.

41. Cinelli, M.; Coles, S.R.; Kirwan, K. Analysis of the potentials of multi criteria decision analysis methods to conduct sustainability assessment. Ecol. Indic. 2014, 46, 138-148. [CrossRef]

42. Chan, K.M.A.; Balvanera, P.; Benessaiah, K.; Chapman, M.; Díaz, S.; Gómez-Baggethun, E.; Gould, R.; Hannahs, N.; Jax, K.; Klain, S.; et al. Opinion: Why protect nature? Rethinking values and the environment. Proc. Natl. Acad. Sci. USA 2016, 113, $1462-1465$. [CrossRef]

43. Cooper, N.; Brady, E.; Steen, H.; Bryce, R. Aesthetic and spiritual values of ecosystems: Recognising the ontological and axiological plurality of cultural ecosystem 'services'. Ecosyst. Serv. 2016, 21, 218-229. [CrossRef] 
44. Barmashova, T.I.; Lazutkina, E.V. Bioethics as effective method for preserving biological diversity on Earth. IOP Conf. Ser. Earth Environ. Sci. 2020, 548, 072050. [CrossRef]

45. INEGI. Anuario Estadístico y Geográfico de Puebla 2017; INEGI: Puebla, Mexico, 2017; p. 940.

46. INEGI. Prontuario de Información Geográfica Municipal de los Estados Unidos Mexicanos; Yaonáhuac, Puebla: Puebla, Mexico, 2009; p. 9. Available online: http://www3.inegi.org.mx/contenidos/app/mexicocifras/datos_geograficos/21/21204.pdf (accessed on 26 January 2017).

47. SEDESOL. Informe Anual Sobre la Situación de Pobreza y Rezago Social 2018 [Internet]. Subsecretaría de Planeación, Evalua-Ción y Desarrollo Regional. 2018. Available online: http:/ / www.dof.gob.mx/SEDESOL/Chiapas_108.pdf (accessed on 16 April 2018).

48. INEGI. Conjunto de Datos Vectoriales de uso de Suelo y Vegetación Escala 1:250,000 Serie V Conjunto Nacional Aguascalien-tes [Internet]. 2013. Available online: https / /:www.inegi.org.mx (accessed on 3 November 2020).

49. Van Asselt, E.; Van Bussel, L.; Van Der Voet, H.; Van Der Heijden, G.; Tromp, S.; Rijgersberg, H.; Van Evert, F.; Van Wagenberg, C.; Van Der Fels-Klerx, H. A protocol for evaluating the sustainability of agri-food production systems-A case study on potato production in peri-urban agriculture in The Netherlands. Ecol. Indic. 2014, 43, 315-321. [CrossRef]

50. Pinedo-Álvarez, C.; Chacón-Chumacero, K.O.; Pinedo-Álvarez, A.; Martínez-Salvador, M.; Rentería-Villalobos, M.; Sante-llanoEstrada, E.; Rodríguez-Piñeros, S. Using Social, Economic and Land-Use Indices to Build a Local Sustainability Index in a Mining Region of the Sierra Tarahumara, Mexico. Resources 2017, 6, 42. [CrossRef]

51. Bonisoli, L.; Galdeano-Gómez, E.; Piedra-Muñoz, L. Deconstructing criteria and assessment tools to build agri-sustainability in-dicators and support farmers' decision-making process. J. Clean. Prod. 2018, 182, 1080-1094. [CrossRef]

52. Barrera-Bassols, N.; Zinck, J.A.; Van Ranst, E. Participatory soil survey: Experience in working with a Mesoamerican indigenous community. Soil Use Manag. 2009, 25, 43-56. [CrossRef]

53. Barrera-Bassols, N.; Alfred Zinck, J.; Van Ranst, E. Symbolism, knowledge and management of soil and land resources in indig-enous communities: Ethnopedology at global, regional and local scales. Catena 2006, 65, 118-137. [CrossRef]

54. Douxchamps, S.; Van Wijk, M.; Silvestri, S.; Moussa, A.S.; Quiros, C.; Ndour, N.Y.B.; Buah, S.; Somé, L.; Herrero, M.; Kristjanson, P.; et al. Linking agricultural adaptation strategies, food security and vulnerability: Evidence from West Africa. Reg. Environ. Chang. 2016, 16, 1305-1317. [CrossRef]

55. Nicholls, C.I.; Altieri, M.A. Pathways for the amplification of agroecology. Agroecol. Sustain. Food Syst. 2018, $42,1170-1193$. [CrossRef]

56. Altieri, M.A.; Nicholls, C.I. The adaptation and mitigation potential of traditional agriculture in a changing climate. Clim. Chang. 2013, 140, 33-45. [CrossRef]

57. González-Chang, M.; Wratten, S.D.; Shields, M.W.; Costanza, R.; Dainese, M.; Gurr, G.M.; Johnson, J.; Karp, D.S.; Ketelaar, J.W.; Nboyine, J.; et al. Understanding the pathways from biodiversity to agro-ecological outcomes: A new, interactive approach. Agric. Ecosyst. Environ. 2020, 301, 107053. [CrossRef]

58. Tremblay, R.; Landry-Cuerrier, M.; Humphries, M.M. Culture and the social-ecology of local food use by Indigenous communities in northern North America. Ecol. Soc. 2020, 25, 1-26. [CrossRef]

59. Dumont, B.; Puillet, L.; Martin, G.; Savietto, D.; Aubin, J.; Ingrand, S.; Niderkorn, V.; Steinmetz, L.; Thomas, M. Incorporating Diversity into Animal Production Systems Can Increase Their Performance and Strengthen Their Resilience. Front. Sustain. Food Syst. 2020, 4, 1-15. [CrossRef]

60. Giraldo, O.F.; Rosset, P.M. Agroecology as a territory in dispute: Between institutionality and social movements. J. Peasant. Stud. 2018, 45, 545-564. [CrossRef]

61. Fagúndez, J.; Izco, J. Diversity patterns of plant place names reveal connections with environmental and social factors. Appl. Geogr. 2016, 74, 23-29. [CrossRef]

62. IPCC. Cambio Climático 2014: Impactos, adaptación y vulnerabilidad-Resumen para responsables de políticas. In Contribución del Grupo de Trabajo II al Quinto Informe de Evaluación del Grupo Intergubernamental de Expertos Sobre Cambio Climático; Field, C.B., Barros, V.R., Dokken, D.J., Mach, K.J., Mastrandrea, M.D., Bilir, T.E., Eds.; OMM; PNUMA: Ginebra, Suiza, 2014 ; p. 34.

63. Segnon, A.C.; Achigan-Dako, E.G.; Gaoue, O.G.; Ahanchédé, A. Farmer's Knowledge and Perception of Diversified Farming Systems in Sub-Humid and Semi-Arid Areas in Benin. Sustainability 2015, 7, 6573-6592. [CrossRef] 